\author{
Elena Pekhtasheva ${ }^{1}$, Anatoly Neverov ${ }^{1}$, Stefan Kubica ${ }^{2}$ \\ and Gennady Zaikov ${ }^{3}$
}

\title{
CLASSIFICATION OF BIODAMAGES, EVALUATION AND PROTECTION METHODS
}

\author{
${ }^{1}$ G.V. Plekhanov Russian Economic University, \\ 36, Stremyannyi way, 117997 M oscow, Russia; pekhtashevael@mail.ru \\ Institut Inzynierii Materialow Polimerowych I Barwnikow, \\ 55 M. Sklodowskiej-Curie str., 87-100 Torun, Poland; S.Kubica@impib.pl \\ ${ }^{3}$ N.M Emanuel Institute of Biochemical Physics, Russian Academy of Sciences, \\ 4, Kosygin str., 119334 M oscow, Russia; chembio@sky.chph.ras.ru
}

Received: October 03, 2011/ Revised: October 17, $2011 /$ Accepted: J anuary 20, 2012

(C) Pekhtasheva E., Neverov A., Kubica S., Zaikov G., 2012

\begin{abstract}
The paper is including information about classification and diagnostics of biodamages, raw materials, materials and products, biostability of materials evaluation methods and methods for material protection against biodamaging. The contributors are discussing the problems of biocides classification, application of antimicrobial materials, requirements to biocides and evaluation methods for antimicrobial properties of biocides.
\end{abstract}

Keywords: classification, biodamages, protection, evaluation, methods, diagnostics, materials, products, biocides, pesticides.

\section{Classification and Diagnostics of Biodamages, Raw Materials, $M$ aterials and Products}

The impact of living organisms on industrial raw materials, materials and products may significantly change their commercial properties, decrease quality and, in a number of cases, cause their complete degradation. These properties of raw materials may be changed during storage, operation and, sometimes, during manufacture due to mechanical, physico-chemical and biological factors, which induce respective damages [1-9].

Meanwhile, the adverse effect of environmental factors on the materials is manifested in the totality of chemical, physical and biological transformations of materials proceeding in parallel or sequentially with the synergic effect. It is unambiguous that at any disturbances of storage conditions, moreover, in emergency biological damages considerably change properties of materials and goods.

According to regulatory documents, the term of biodamage is defined as a raw material, material and product damaged by any biological factor [10]. Biological factor (biofactor) represents organisms or biocenoses which disturb the operable condition of an object. However, these formulations presented in the standard [10] do not describe the influence of commercial goods damages on safety - one of the most important commercial properties. Safety is the absence of any risk for life, health and the property of customers during operation or consumption of goods.

With respect to the origin of impacts on safety, hygienic safety means the absence of impermissible risk, which may occur in case of various biodamages of commercial goods, and which, in turn, may not only cause property loss, but may also be dangerous for the customer health. This particularly concerns contamination of goods by pathogenic microorganisms.

However, not only pathogens can be dangerous for the customer health. For example, at some textile mills cases of workers' diseases in the spinning and prep areas due to high dust release with saprophytes to the atmosphere from biologically polluted cotton were detected. When evaluating hygienic properties of clothes, underwear, shoes and other products, the level of microorganism accumulation in them is determined. It is assumed that the higher accumulation of microorganisms on the underwear and inside the shoes (footwear garments, inner soles), the lower is their abundance on the consumer skin surface. It is found that bacterial content on 
the human skin when using clothes and underwear from cotton and viscose is 2-3-fold lower, than for caprone underwear [11].

Thus, biodamages are tightly associated with the complex quality characteristics of goods, such as reliability, functionality, ergonomics, etc.

The objects of biodamages are raw materials, materials, products and facilities, the properties of which are changed in the course of living organism impact. Biodamaging agents are living organisms, which attack these objects and induce changes in their properties (Table 1).

Table 1

Biodamaging agents (biofactors)

\begin{tabular}{|l|l|l|}
\hline Microbiological & Phytological & Zoological \\
\hline Bacteria & Mosses & Insects \\
Microscopic fungi & Lichens & Birds \\
Blue-green algae & Higher plants & Mammals \\
& Algae & \\
\hline
\end{tabular}

Under real storage and operation conditions, the raw materials, materials and products are damaged by microorganisms (bacteria, microscopic fungi), insects (moths, leather beetles, wood fretters, termites, bugs) and animals (rodents - rats and mice).

Resistance to biological factor action (biostability) is the property of an object to preserve its own parameters within the limits set in the standard technical documentation in the given time in the course and after a biofactor impacting. This term is applied with particular biofactor indication:

- bacterial stability - the resistance to bacterium impact;

- fungal stability - the resistance fungus impact;

- the resistance to damaging by termites;

- the resistance to damaging by moth;

- the resistance to damaging by rodents;

- microbiological stability - the resistance of materials to a group of microorganisms (bacteria, fungi) in the course of biostability tests under natural conditions [10].

The impact of living organisms on materials may cause and adverse a favorable effect for the man. In the first case, we mean biodeterioration or biodamaging, and in the second case - biodegradation of warn out materials, which pollute the environment [5, 12-17]. Biotechnology may be applied to biofinishing, e.g. of textile materials [15].

Fig. 1 shows a diagram of living organisms impacting on the raw materials, materials and products which, in addition to the traditional one, shows microbiological processes of biodegradable polymer creation and biofinishing [12-18].
Among biodamages, damages of the biological type (the first type of impact in the diagram) will be outlined, which across a variety of living organisms and ways of their action may lead to biochemical and mechanical changes in materials. In this case, microorganisms mostly cause a biochemical effect on the materials, whereas insects and animals damage them mechanically $[6,18]$.

Thus, damages of the biological type of materials caused by microorganisms can be divided into two groups:

- The use of materials as energy and nutrition source: for microorganisms, this is assimilation; and for insects and rodents, this is "food" damages;

- Impact on the material with it mechanical or chemical destruction: for microorganisms, this is degradation; and for insects and rodents, this is "no-food" damages.

It should be noted that among all microorganisms, microscopic fungi may also promote mechanical destruction of materials due to fungus mycelium hyphae overgrowth, which induces high turgor pressure.

The second type of living organism (mostly microorganisms and plants) impact on the raw material, materials and products is the surface overgrowth. It may be accompanied by biochemical impact on the material or proceed without it [1, 2, 6-8].

The third type of the biological factor impact is biocontamination. Biological contamination of an object (biocontamication) is the object condition in the presence of a biofactor, after removal of which functional properties of the object are recovered [10].

Thus, microorganisms developing on materials and substrates may be distinguished by nutrition types. Some consume organic substances of the material, as the source of energy and nutrition (assimilation). Others are developed using metabolites, which damage materials (degradation). There are microorganisms, developing on the material surface due to mineral and organic contaminants accumulated on it, but not affecting the entire material. They have no effect on the material properties, but just cause biocontamination [8].

Damages caused by insects are of food and nonfood types [19, 20]. In most cases, larvae inhabiting inside the material or on its surface consume it as nutrition. If products have cavities and holes suitable for insect inhabitance, only internal contamination of the product is possible. If insects developing in material cavities consume it for construction, e.g. as some moth worms making spathella, the material itself is somewhat damaged yet. Consumption of plant and animal materials as a nutrition is the most typical for pests, plant material pests being more variable. 


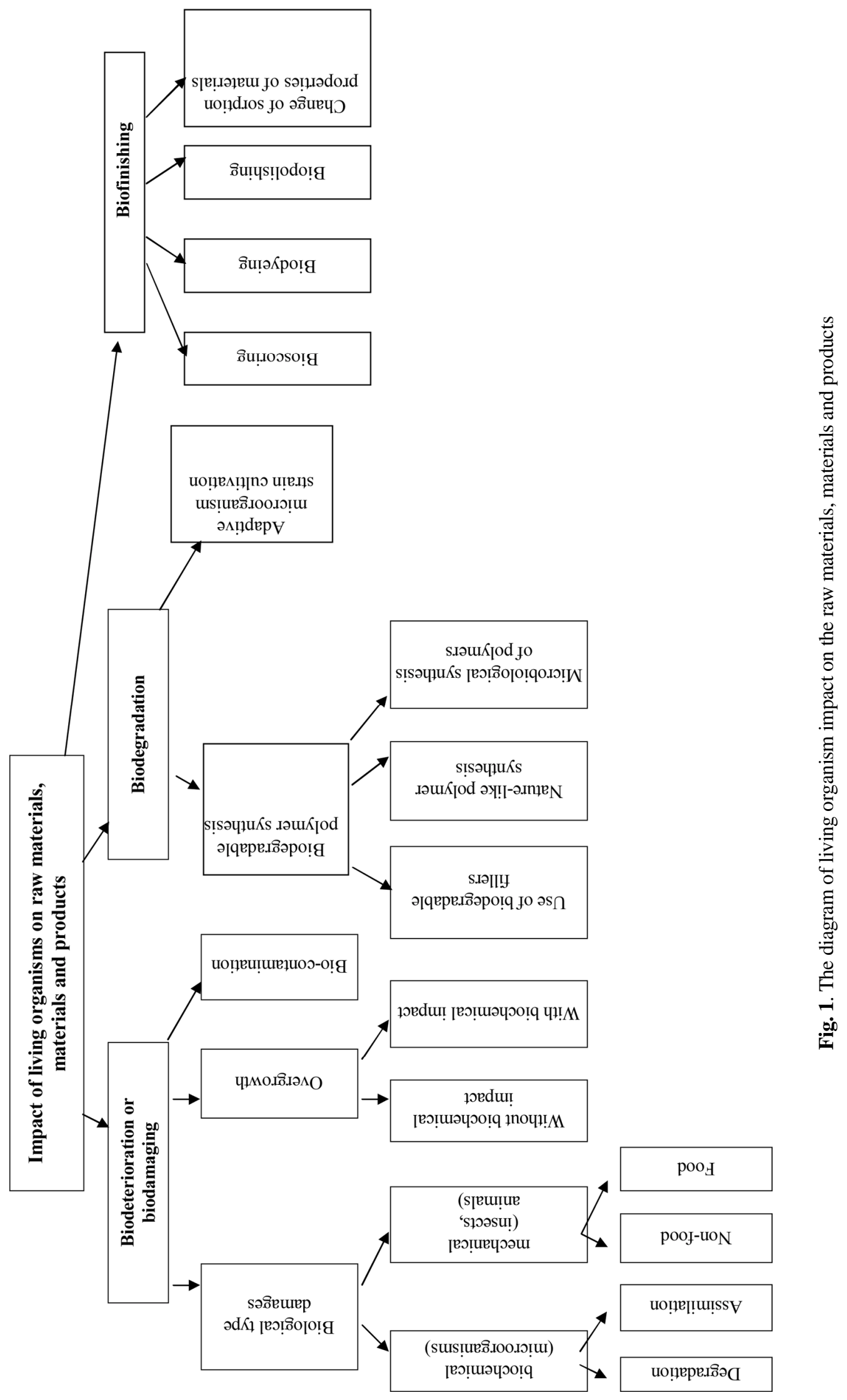


Table 3

Classification of material defects caused by microorganisms by the level of significance

\begin{tabular}{|c|c|c|c|c|c|}
\hline \multirow[b]{2}{*}{ Materials } & \multirow[b]{2}{*}{$\begin{array}{c}\text { Insignificant } \\
\text { (biocontamination) }\end{array}$} & \multirow[b]{2}{*}{ Significant } & \multicolumn{3}{|c|}{ Critical } \\
\hline & & & Organoleptic changes & $\begin{array}{l}\text { Material } \\
\text { structure } \\
\text { change }\end{array}$ & $\begin{array}{c}\text { Physico-mechanical } \\
\text { and physico- } \\
\text { chemical property } \\
\text { change }\end{array}$ \\
\hline $\begin{array}{l}\text { 1. Inorganic } \\
\text { metals }\end{array}$ & $\begin{array}{l}\text { Microscopic visible } \\
\text { adsorption of }\end{array}$ & $\begin{array}{l}\text { Presence of } \\
\text { mucus, visible } \\
\text { mold blooms } \\
\text { covering at }\end{array}$ & $\begin{array}{l}\text { Presence of mucus } \\
\text { covering over } 25 \% \text { of the } \\
\text { surface }\end{array}$ & $\begin{array}{l}\text { Metal surface } \\
\text { corrosion }\end{array}$ & $\begin{array}{l}\text { - Strength } \\
\text { parameter decrease } \\
\text { - Electroconductive } \\
\text { property change } \\
\text { - Mass loss after } \\
\text { biocorrosion } \\
\text { product removal }\end{array}$ \\
\hline - silicates & & $\begin{array}{l}\text { least } 25 \% \text { of } \\
\text { the surface }\end{array}$ & $\begin{array}{l}\text { - Presence of mucus } \\
\text { covering over } 25 \% \text { of the } \\
\text { surface } \\
\text { - Glitter loss and } \\
\text { transparency decrease }\end{array}$ & $\begin{array}{l}\text { Glass surface } \\
\text { corrosion }\end{array}$ & $\begin{array}{l}\text { Light transmittance } \\
\text { and light scattering } \\
\text { decrease }\end{array}$ \\
\hline $\begin{array}{l}\text { 2. Organic } \\
\text { chemical } \\
-\quad \text { polymers } \\
\text { (plastics, textile } \\
\text { fibers) }\end{array}$ & $\begin{array}{l}\text { Microscopic visible } \\
\text { adsorption of } \\
\text { microorganisms }\end{array}$ & $\begin{array}{l}\text { Presence of } \\
\text { mucus, visible } \\
\text { mold blooms } \\
\text { covering at } \\
\text { least } 25 \% \text { of } \\
\text { the surface }\end{array}$ & $\begin{array}{l}\text { - Presence of mucus, } \\
\text { mold blooms covering at } \\
\text { least } 25 \% \text { of the surface } \\
\text { - Putrefactive odor } \\
\text { - Coloring change, } \\
\text { spots. } \\
\text { - Surface roughness. } \\
\text { - Glitter disappearing. } \\
\text { - Cracking }\end{array}$ & $\begin{array}{l}\text { - Surface } \\
\text { corrosion } \\
\text { - Filler } \\
\text { degradation }\end{array}$ & $\begin{array}{l}\text { - Strength } \\
\text { parameter decrease } \\
\text { - Hardness } \\
\text { decrease } \\
\text { - Flexibility } \\
\text { decrease } \\
\text { - Viscosity } \\
\text { decrease } \\
\text { - Electroconductive } \\
\text { property change }\end{array}$ \\
\hline $\begin{array}{l}\text { 3. Organic } \\
\text { natural } \\
\text { - wood }\end{array}$ & $\begin{array}{l}\text { Microscopic visible } \\
\text { adsorption of } \\
\text { microorganisms }\end{array}$ & $\begin{array}{l}\text { Presence of } \\
\text { mucus, visible } \\
\text { mold blooms } \\
\text { covering at } \\
\text { least } 25 \% \text { of } \\
\text { the surface }\end{array}$ & $\begin{array}{l}\text { - Presence of mucus, } \\
\text { mold blooms covering at } \\
\text { least } 25 \% \text { of the surface } \\
\text { - Mold odor } \\
\text { - Occurrence of } \\
\text { differently colored spots } \\
\text { - Easily decomposes to } \\
\text { powder }\end{array}$ & $\begin{array}{l}\text { Vessel cellular } \\
\text { membrane } \\
\text { destruction }\end{array}$ & $\begin{array}{l}\text { - Mass loss } \\
\text { - Strength } \\
\text { parameter decrease } \\
\text { - Waterproof } \\
\text { property increase }\end{array}$ \\
\hline $\begin{array}{l}\text { - paper, } \\
\text { cardboard }\end{array}$ & & & $\begin{array}{l}\text { - Mold presence } \\
\text { - Pigment dyeing } \\
\text { - Mold odor }\end{array}$ & $\begin{array}{l}\text { Fiber } \\
\text { destruction up } \\
\text { to complete } \\
\text { dissolution }\end{array}$ & $\begin{array}{l}\text { - Mass loss } \\
\text { - Breaking strength } \\
\text { decrease }\end{array}$ \\
\hline $\begin{array}{l}\text { - textile fibers, } \\
\text { fabrics, tricot, } \\
\text { nonwoven }\end{array}$ & & & $\begin{array}{l}\text { - Presence of mucus, } \\
\text { mold blooms } \\
\text { - Putrefactive odor } \\
\text { - Color change }\end{array}$ & $\begin{array}{l}\text { - Stratification } \\
\text { (fibrillation). } \\
\text { - Deep } \\
\text { membrane } \\
\text { damage. } \\
\text { - Decay to } \\
\text { conglomerates }\end{array}$ & $\begin{array}{l}\text { - Strength } \\
\text { parameter decrease } \\
\text { - Mass loss }\end{array}$ \\
\hline - leather, fur & & & $\begin{array}{l}\text { - Presence of mucus, } \\
\text { mold blooms } \\
\text { - Putrefactive odor } \\
\text { - Sliming } \\
\text { - Hairslip } \\
\text { - Spots } \\
\text { - Facial layer roughness }\end{array}$ & $\begin{array}{l}\text { - Gelation and } \\
\text { collagen yarns } \\
\text { dissolution and } \\
\text { fuse } \\
\text { - Hair bulb } \\
\text { decomposition } \\
\text { - Epidermis } \\
\text { exfoliation }\end{array}$ & $\begin{array}{l}\text { - Strength } \\
\text { parameter decrease } \\
\text { - Hygroscopy } \\
\text { increase }\end{array}$ \\
\hline
\end{tabular}


Types of material damages caused by various biofactors

\begin{tabular}{|c|c|c|c|c|c|c|c|c|c|c|c|c|c|c|c|c|}
\hline \multirow[b]{3}{*}{ Materials } & \multicolumn{4}{|c|}{ Microorganisms } & \multicolumn{10}{|c|}{ Insects } & \multicolumn{2}{|c|}{ Rodents } \\
\hline & \multicolumn{2}{|c|}{ Bacteria } & \multicolumn{2}{|c|}{ Fungi } & \multicolumn{2}{|c|}{ Moths } & \multicolumn{2}{|c|}{$\begin{array}{l}\text { Leather } \\
\text { beetles }\end{array}$} & \multicolumn{2}{|c|}{$\begin{array}{l}\text { Wood } \\
\text { fretters }\end{array}$} & \multicolumn{2}{|c|}{ Termites } & \multicolumn{2}{|c|}{ Bugs } & \multirow[b]{2}{*}{ 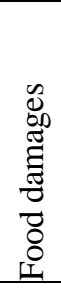 } & \multirow{2}{*}{$\begin{array}{l}0 \\
0 \\
\tilde{0} \\
\tilde{E} \\
0 \\
0 \\
0 \\
0 \\
0 \\
z \\
z\end{array}$} \\
\hline & 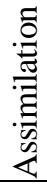 & 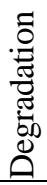 & 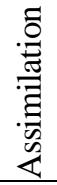 & 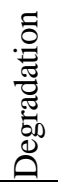 & $\begin{array}{l}\overline{8} \\
0 \\
\end{array}$ & $\begin{array}{l}\overrightarrow{0} \\
8 \\
0 \\
1 \\
0 \\
z\end{array}$ & $\begin{array}{l}8 \\
8 \\
\end{array}$ & $\begin{array}{l}\vec{Z} \\
8 \\
0 \\
0 \\
z \\
z\end{array}$ & $\begin{array}{l}\overline{8} \\
8 \\
\end{array}$ & $\begin{array}{l}8 \\
8 \\
8 \\
8 \\
z \\
\end{array}$ & $\begin{array}{l}\overline{8} \\
\\
\end{array}$ & $\begin{array}{l}0 \\
8 \\
0 \\
11 \\
0 \\
z \\
\end{array}$ & $\begin{array}{l}\text { Z } \\
\\
\end{array}$ & 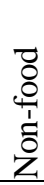 & & \\
\hline $\begin{array}{l}\text { Inorganic: } \\
\text { - Metals }\end{array}$ & - & + & - & $\mathrm{x}$ & - & - & - & - & - & - & - & - & - & - & - & $\mathrm{x}$ \\
\hline - Silicates & - & $\mathrm{x}$ & - & + & - & - & - & - & - & - & - & - & - & - & - & \\
\hline $\begin{array}{l}\text { Organic } \\
\text { chemical: } \\
\text { - Polymers } \\
\text { - Synthetic } \\
\text { fibers }\end{array}$ & $\begin{array}{l}+ \\
+\end{array}$ & $\begin{array}{l}+ \\
+\end{array}$ & $\begin{array}{l}+ \\
+\end{array}$ & $\begin{array}{l}+ \\
+\end{array}$ & - & $\begin{array}{l}\mathrm{X} \\
\mathrm{x}\end{array}$ & $\begin{array}{l}- \\
-\end{array}$ & $\begin{array}{l}\mathrm{x} \\
\mathrm{x}\end{array}$ & $\begin{array}{l}- \\
-\end{array}$ & $\begin{array}{l}- \\
-\end{array}$ & $\begin{array}{l}- \\
-\end{array}$ & $\begin{array}{l}x \\
x\end{array}$ & $\begin{array}{l}\mathrm{X} \\
\mathrm{X}\end{array}$ & $\begin{array}{l}x \\
x\end{array}$ & $\begin{array}{l}- \\
-\end{array}$ & $\begin{array}{l}\mathrm{x} \\
\mathrm{x}\end{array}$ \\
\hline $\begin{array}{l}\text { Organic } \\
\text { natural: } \\
\text { - Wood, paper }\end{array}$ & $\mathrm{x}$ & $\mathrm{x}$ & + & + & - & $\mathrm{x}$ & - & $\mathrm{x}$ & + & + & + & + & $\mathrm{x}$ & $\mathrm{x}$ & $\mathrm{x}$ & + \\
\hline - Textile fibers & + & + & + & + & + & + & $\mathrm{x}$ & $\mathrm{x}$ & - & $\begin{array}{c}- \\
-\end{array}$ & + & + & $\mathrm{x}$ & $\mathrm{x}$ & $\mathrm{x}$ & + \\
\hline $\begin{array}{l}\text { - Leather, fur } \\
\text { (prepared) }\end{array}$ & $\mathrm{x}$ & $\mathrm{x}$ & + & + & + & + & + & + & - & - & + & + & $\mathrm{x}$ & $\mathrm{x}$ & + & + \\
\hline - Rawhide & + & + & $\mathrm{x}$ & $\mathrm{x}$ & + & + & + & + & - & - & + & + & $\mathrm{x}$ & $\mathrm{x}$ & + & + \\
\hline
\end{tabular}

Notes: - not available; $\mathrm{x}$ - infrequently available; + - available.

Table 4

Classification of material defects by level of significance under the impact of insects and rodents

\begin{tabular}{|c|c|c|c|c|c|c|}
\hline \multirow[b]{2}{*}{ Materials } & \multicolumn{3}{|c|}{ Insects } & \multicolumn{3}{|c|}{ Rodents } \\
\hline & $\begin{array}{c}\text { Insignificant } \\
\text { (biocontaminatio } \\
\mathrm{n} \text { ) }\end{array}$ & Significant & Critical & $\begin{array}{l}\text { Insignificant } \\
\text { (biocontaminat } \\
\text { ion) }\end{array}$ & Significant & Critical \\
\hline $\begin{array}{ll}\text { 1. } & \text { Inorganic } \\
- & \text { Metals } \\
- & \text { Silicates } \\
\end{array}$ & \multirow{2}{*}{$\begin{array}{l}\text { Ichnofossils in } \\
\text { devices and } \\
\text { equipment }\end{array}$} & \multirow{2}{*}{$\begin{array}{l}\text { Abundant } \\
\text { traces of } \\
\text { presence } \\
\text { (bugs) in } \\
\text { devices and } \\
\text { equipment }\end{array}$} & $\begin{array}{l}\text { Traces of } \\
\text { presence }\end{array}$ & $\begin{array}{l}\text { Traces of } \\
\text { presence }\end{array}$ & $\begin{array}{l}\text { Contamination } \\
\text { by turds and } \\
\text { hair }\end{array}$ & $\begin{array}{l}\text { Contamination } \\
\text { by pathogens. } \\
\text { Nibbles }\end{array}$ \\
\hline $\begin{array}{l}\text { 2. Organic } \\
\text { chemical } \\
-\quad \text { polymers } \\
\text { (plastics, } \\
\text { textile fibers) }\end{array}$ & & & $\begin{array}{l}\text { Pollution by } \\
\text { pathogens }\end{array}$ & $\begin{array}{l}\text { Traces of } \\
\text { presence }\end{array}$ & $\begin{array}{l}\text { Contamination } \\
\text { by turds and } \\
\text { hair }\end{array}$ & $\begin{array}{l}\text { Contamination } \\
\text { by pathogens. } \\
\text { Nibbles }\end{array}$ \\
\hline $\begin{array}{l}\text { 3. Organic } \\
\text { natural } \\
\text { - wood } \\
\text { - paper, } \\
\text { cardboard } \\
\text { - textile } \\
\text { fibers, } \\
\text { fabrics, tricot, } \\
\text { nonwoven } \\
\text { - leather, fur }\end{array}$ & Ichnofossils & $\begin{array}{l}\text { Contaminati } \\
\text { on by skins, } \\
\text { turds, the } \\
\text { presence of } \\
\text { eggs and } \\
\text { larvae }\end{array}$ & $\begin{array}{l}\text { Traces of } \\
\text { presence } \\
\text { Loss of a part of } \\
\text { material: } \\
\text { - wormholes } \\
\text { - nibbles } \\
\text { - moth holes } \\
\text { - grease beetle } \\
\text { damage }\end{array}$ & $\begin{array}{l}\text { Traces of } \\
\text { presence }\end{array}$ & $\begin{array}{l}\text { Contamination } \\
\text { by turds and } \\
\text { hair }\end{array}$ & $\begin{array}{l}\text { Contamination } \\
\text { by pathogens. } \\
\text { Nibbles }\end{array}$ \\
\hline
\end{tabular}


Among living organisms damaging materials, rodents occupy a special position, because damages they make are most frequently of the non-food type, associated with manifestation of their physiological features (gnawing activity).

According to our reckoning, damages of various materials and products affected by various biofactors may be reduced to the following types (Table 1) [18].

The impact of living organisms on the raw material, materials and products result in occurrence of defects in them. By the level of significance, defects are distinguished, as critical, significant and trifling. Critical defects represent inadequacy of products to set requirements that may be harmful to health or property of customers or to the environment. Significant effects represent inconsistencies affecting properties of materials, but not appearing unsafe for the customer or the environment. Trifling defects are inadequacies having not effect on the product properties, first of all, on the purpose, reliability and safety. They are, in particular, biocontamination not associated, e.g., with pathogens [11].

When analyzing the cited references [1-8, 19], we have classified and systematize defects by types occurring under the impact of living organisms on the raw materials, materials and products of various origins. Moreover, integrating data on changes of properties and structures of various objects (materials) occurring at critical biological defects are shown (see Tables 2-4) for results.

With respect to the existence of detection methods, defects are divided into obvious ones, for which detection methods and means are provided, and hidden, for which detection methods and means are unavailable or they are undesirable. Hidden defects are most typical of biodamages, and their detection requires special equipment.

With respect to the presence of methods and means for elimination, defects are divided into recoverable and unrecoverable. Recoverable defects are those, after which elimination of the material can be used as intended. Such defects are only typical of biocontamination. Unrecoverable defects cannot be eliminated or they are economically unsound. For instance, in case of optics biodamage, a device can be recovered by dismantling and glass surface polishing. In other cases, critical defects caused by biodamage are virtually unrecoverable.

Thus, biodamaging of raw materials, materials and products result in the following processes:

- a change of chemical properties as a result of oxidation or hydrolysis of material components (acid and alkaline resistance, resistance to oxidants, deoxidants and organic solvents);

- a change of physicomechanical properties of materials (strength loss by wood, rubber, plastics, fabrics, rubber swelling, varnish cover adhesion loss);
- a change of optical properties (color, glitter, transparency and material properties);

- deterioration of electrophysical properties (reduction of insulating properties of materials);

- a change of organoleptic properties (occurrence of smell, mucus on solid surfaces);

- loss of a part of material due to its damage (by rodents or insects).

The result of microorganism impact on materials favorable for a man can be obtained using bioutilization (biodegradation) and biofinishing [14, 20].

Polymeric material waste is the source of environmental pollution. Single-use package and packing materials are particularly hazardous. Polymers capable of preserving properties during operation and only then biodegrade are now developed and synthesized [21].

The main directions for obtaining biodegradable polymers are: creation of polymeric composites containing various fillers, which are nutrition for microorganisms; creation of photodegradable polymers able to be degraded to low-molecular fractions, which are then degraded by the soil microflora; creation of polymers having structure similar to natural polymers: microbiological synthesis of polymers (biopolymers) [20].

The important direction of bioutilization is cultivation of special adaptive microorganism strains capable of degrading particular materials.

One of directions in the modern research of useful activity of the microorganisms is creation of "biopolymers". Even today there are suggestions on the synthesis of various polysaccharides using microbiological methods, which may be used for obtaining fiber-forming monomers and polymers. For instance, some polyethers can be obtained by direct microbiological synthesis [22, 23].

Basing on microbiological synthesis, some kinds of fibroin-like fiber-forming polypeptides were obtained. In some cases, the contents of these products may reach $40 \%$ of biomass quantity and they can be used as a perspective raw material for obtaining chemical fibers.

The favorable result of microorganism use can be obtained, for example, by applying various variants of textile biofinishing. The application of enzymes allows actively displace common, ecologically unfriendly chemical technologies in the finishing.

The enzyme technologies are most widely applied to cleaning textile materials from various contaminants (bioscoring) to remove sizing agents, to clean and bleach cotton and linen, and to remove pectic satellites, etc. [15].

Fabric dyeing technology in the presence of enzymes has been developed. These technologies improve coloristic characteristics of the products, meanwhile, reducing content of noxious agents in the sewage. The 
application of enzymes in dyed fabric processing is of high industrial importance. This processing fades products irregularly, imparting them a stylish "shabby" fashion.

Enzymes are also used to improve hygienic, e.g. sorption properties of synthetic textile fibers. Enzymes have been shown to be able to hydrolyze ether bonds on the surface of polyether fibers. Biotechnologies are used for biopolishing of cotton or woolen products to make them smooth and reduce the pilling degree.

\section{Biostability of Materials Evaluation Methods}

The materials for stability to the action of microorganisms are both laboratory and field tested.

Long-term field tests give the most reliable data on biostability of the materials. They are performed under natural conditions (at climatic stations) both on open stands and in special rooms protected against direct sunlight, with restricted aeration and increased humidity. Material and product specimens are placed on the stands at an angle of $45-75^{\circ}$ to provide precipitation of atmospheric dust, plant residues, etc. on their surface.

There are many laboratory methods for evaluating biostability of industrial materials and goods, which can be classified by various signs.

The methods are distinguished by:

- applied biofactors (soil microflora, spontaneous microflora, microscopic fungi, bacteria, insects, rodents);

- exposure conditions (humidity, temperature, dessicators, climatic chambers, Petri dishes, flasks, exposure periods);

- result evaluation methods (mechanical strength loss and mass loss of the specimens, material structure change), type of evaluation (visual four or five point score), microflora abundance on the materials, biomass increment, and other physicochemical methods.

The soil method is one of the most widespread biostability investigation methods for textile materials, plastics, rubbers and other nonmetal materials in Russia. Soil of the following composition is prepared: horse dung, garden soil and sand in 1:1:1 ratio, with $\mathrm{pH}$ 6-7.5. Ready soil layer $25 \mathrm{~cm}$ thick, having $28 \%$ humidity is applied on the material specimen, which is then placed to a humid chamber for a definite time and exposed to 297-299 K. The strength at break is tested after exposure. The method shows a wide scatter of the data and poor reproducibility.

Another example may be a test for mold fungus stability. Sterile Petri dishes are filled with a culture medium. After the medium is solidified, a test specimen is placed on it and treated (inoculated) by a suspension of test-culture spore set and then exposed in a thermostat at
$302 \pm 1 \mathrm{~K}$ during 14 days. The specimens are inspected, and funginertness is assessed in points by the overgrowth rate.

Visual inspection of specimens (the score) is the most frequently used criterion of biostability assessment in standard methods. For instance, the overgrowth by microscopic fungi is scored as follows:

- 0 - no growth of mold fungi is observed under the microscope;

- 1 - sprouted spores and insignificantly developed mycelium shaped as non-branching hyphae are observed under the microscope;

- 2 - mycelium with branching hyphae is observed under the microscope, fruiting is possible;

- 3 - fungus growth is just visible with the naked eye, but is clearly observed under the microscope;

- 4 - fungus growth is clearly visible with the naked eye, covering less than $25 \%$ of the tested surface;

- 5 - fungus growth is clearly visible with the naked eye, covering over $25 \%$ of the tested surface.

Fabric damage degree by moth can be evaluated in points:

- 0 - no damage observed;

- 1 - insignificant damages of the fabric surface, low-observable fleece damage;

- 2 - gnawing from edges, considerable fleece damage;

- 3 - through holes.

Fabric damage degree by rodents can be evaluated in points:

- 0 - no damage observed;

- 1 - tooth marks (shallow scratches);

- 2 - cover and surface of the specimen are damaged (by the specimen edge nibbles are observed);

- 3 - the specimen is significantly damaged, but not gnawed through

- 4 - the specimen is gnawed through.

There are the following examples of evaluation of changes in the material structure:

- standard rating of structure damageability and bacterial pollution of undressed fur skins;

- the method of quantitative evaluation of textile fiber damageability suggested by Prof. I.A. Ermilova.

For fur skins, 4 damageability ratings are determined (by study of dyed histological sections of the leather under the microscope):

1. Normal skins (no structural damages and bacterial pollution):

- full safety of the microstructure with clear detection of cell nuclei;

dyeing;

- collagen yarns with clear contours and smooth 
- tight contact between epidermis and the dermis;

- root sheath of the hair follicle is intensively indigo blue dyed with weak definition of boundaries of spindle-shaped cells forming it;

- the skin contains no bacteria (or they are present on the hide shreds only).

2. Low damage and bacterial pollution:

- dyeing of cellular structure nuclei is slightly less intensive;

- collagen yarns with clear contours and smooth dyeing;

- tight contact between epidermis and the dermis;

- in some hair follicles, initial signs of damage of the internal root sheath occur, manifested in formation of gaps between spindle-shaped cells composing it, i.e. disturbance of their cohesion;

- single bacteria in the lower part of reticular layer of the leather.

3. Middle damage and bacterial pollution:

- dyeing of cellular structure nuclei is abruptly weakened;

- epidermis exfoliates (the loss of connection with its dermis);

- in some hair follicles damages are clearly manifested: follicle disturbance, internal root sheath cover decomposition into spindle-like cells;

- swollen collagen yarns with unclear, fuzzy edges in the reticular layer (initial signs of gelatination);

- bacteria penetrate deep in the papillary and reticular layers of the leather forming agglomerates.

4. High damage and bacterial pollution:

- dyeing of cellular structure nuclei is virtually absent;

- the majority of hair follicles has deep degradation level (destruction of covers and follicles);

- epidermis is exfoliated or completely absent;

- high gelatination of yarns, possible indigo blue dyeing of separate area;

- collagen yarns may be fused in specific formations of irregular shape;

- the leather is penetrated by bacteria;

- exfoliation and decay of the leather tissue.

To evaluate bacterial pollution of the rawhide and woolen fibers, it is also suggested to use the index by Prof. A.I. Sapozhnikova characterizing discoloration degree of resazurin solution, which is a weak organic dye and, in this case, is the hydrogen acceptor and indicates both the presence and activity of reductase enzyme. This gives an opportunity to judge about the amount of active microorganisms present in the studied objects by the discoloration degree [24].

For textile fibers, the evaluation method of degradation degree based on the study of fiber macrostructure using optical microscopy and quantitative accounting for all kinds of fiber damages induced by microorganisms can be used.

All types of damages are divided into three classes:

Class $\mathrm{A}$ is characterized by the totality of initial changes of the fiber surface: overgrowth by microorganisms and their metabolites (Fig. 2). Class B unites higher manifestations of degradation: swellings, thinning, wall damages (Figs. 3 and 4).

Class $\mathrm{C}$ includes strong and deep damages of fibers caused by microorganisms: exfoliation, fiber decay to separate conglomerates (Fig. 5).

Class A damages do not affect the change of internal structure and fiber properties. However, occurrence of these initial degradation stages allows judging about initiation of the fiber damaging process which, under particular conditions, may advance.

Class B damage occurrence is accompanied by degradation of both the surface and internal areas of the fiber. Similar damages affect changing of the fiber properties (e.g. their strength is reduced).

Class $\mathrm{C}$ damage occurrence testifies the deep biological degradation of the fiber structure. Mechanical properties of the fibers with predominant damages of this kind are abruptly reduced.

To evaluate the damage rate of fibers, the following indices are used:

- $\quad N$ is the total quantity of damages;

- $x_{1}$ is the quantity of class A damages;

- $x_{2}$ is the quantity of class B damages;

- $x_{3}$ is the quantity of class $\mathrm{C}$ damages.

The fiber degradation index is calculated by the formula as follows:

$K\left(x_{1}, x_{2}, x_{3}\right)=K_{1}+K_{2}+K_{3} ; K_{1}=\alpha_{1} x_{1} ; K_{2}=\alpha_{2} x_{2} ;$ $K_{3}=\alpha_{3} x_{3} ; K\left(x_{1}, x_{2}, x_{3}\right)=\alpha_{1} x_{1}+\alpha_{2} x_{2}+\alpha_{3} x_{3}$

where $K$ is the biodegradation index; $\alpha_{1}, \alpha_{2}, \alpha_{3}$ are weighting coefficients of class $\mathrm{A}, \mathrm{B}$ and $\mathrm{C}$ damages, respectively. $\alpha_{1}=0.002 ; \alpha_{2}=0.025 ; \alpha_{3}=0.255$.

Changes in the fiber degradation index within the range of $0-0.3$ correspond to initial changes of the fiber surface, not involving its internal structure. In the range of 0.3-3.55, degradation of both surface and internal areas of the fibers is observed, accompanied by the initial changes, and in the range of 3.55-42.25 deep biological degradation of the fiber structure at all its levels is observed. 

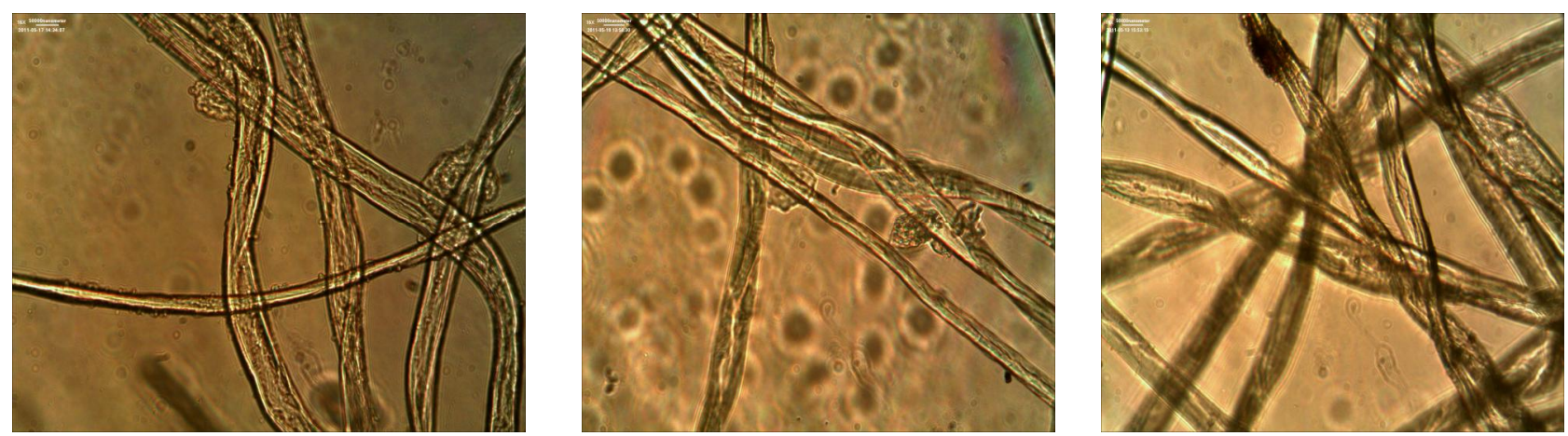

Fig. 2. Kinds of textile fiber damages by microorganisms (on the example of cotton fibers, $x 400$ ):- overgrowth (class A)
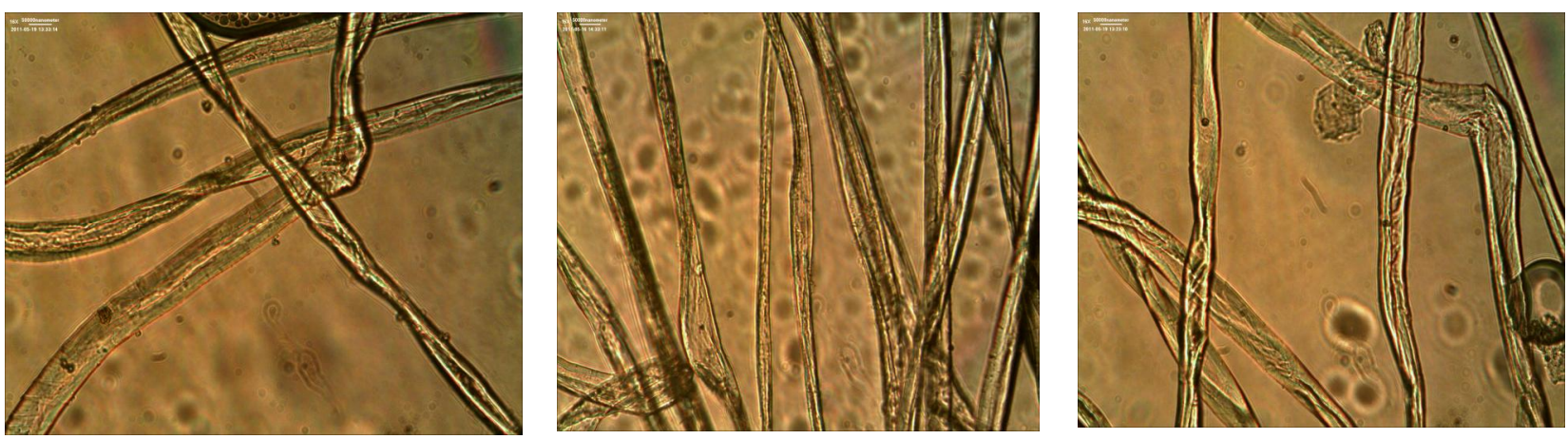

Fig. 3. Kinds of textile fiber damages by microorganisms (on the example of cotton fibers, $x 400$ ): - swelling (class B)
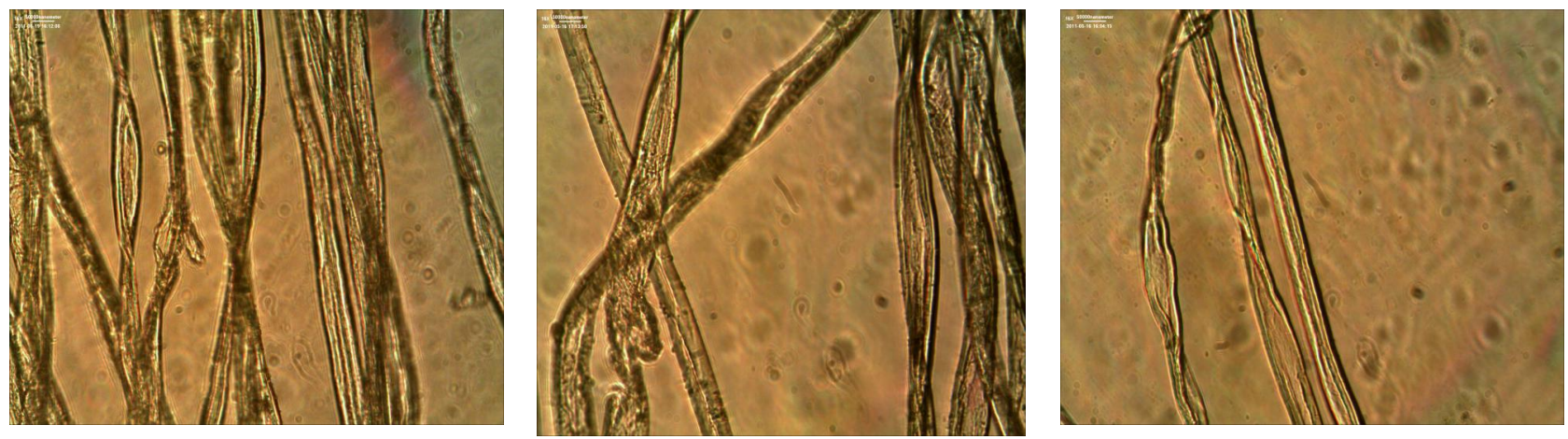

Fig. 4. Kinds of textile fiber damages by microorganisms (on the example of cotton fibers, $\mathrm{x} 400$ ): - wall damage (class B)
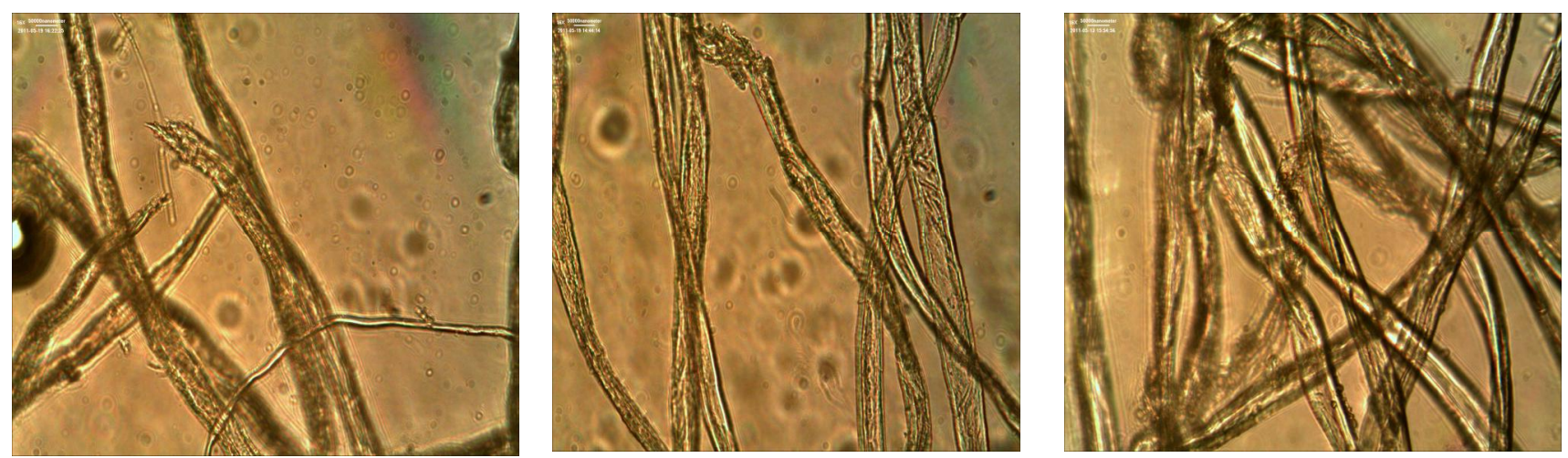

Fig. 5. Kinds of textile fiber damages by microorganisms (on the example of cotton fibers, $\mathrm{x} 400$ ): - granular disintegration (class C) 


\section{Methods for M aterial Protection against Biodamaging}

Among basic methods of the material protection against biodamaging by microorganisms the following ones can be outlined:

1. Mechanical removal of contamination.

2. Maintaining of proper hygienic and temperature-humidity conditions $(293>t, \mathrm{~K}>333$; relative humidity of the ambient air below $80 \%$, aeration).

3. Physical methods (bacterial filters, electromagnetic, radiation and ultraviolet radiation, ultrasound, electrochemical protection).

4. Hydrophobization of the surface.

5. Prevention of microorganism penetration to the biodamage object (sealing, air cleaning, vacuum, biocide gaseous atmosphere).

6. Elimination of one of the components necessary for microbial propagation (e.g. the use of chelate iron and magnesium compounds binding metals necessary for microorganism propagation).

7. Biological protection (antagonism, competitive microorganisms).

8. Creation of materials with the given biostability (one or several components of the material have biocide properties).

9. Application of biocide compounds is one of the most efficient and widespread protection methods.

At present, bactericide filters used for cleaning fuels, lubricants, processing media and other liquids and gases represent the mechanical protection. Liquids can be purified from viable microflora by ion-exchange resins, glass ceramic filters, membrane filters, etc.

Designing of dust-humid-air-proof systems preventing microorganism penetration to various materials and products is also the mechanical protection method. These methods are simple and highly efficient. However, their application is limited, because they are suitable for a short number of materials.

Physical methods are widely applied to protect optical devices from biodamages, e.g. internal heating units, high frequency currents, UV sterilization during instrument assembly have been suggested.

Gamma-radiation is effectively applied to sterilize IC chips, medical-purpose articles, and drugs. It is found that 3 Mrad $\gamma$-radiation dose guarantees elimination of mold fungi and keeps ceramic showpieces of archeological museums presentable.

To protect jet fuels, lubricants and other special liquids, ionizing radiation, electromagnetic fields and ultraviolet light can be used.

One of the ways to sterilize paper and other temperature-sensitive materials is the use of low-pressure plasma.
The advantage of this method is short sterilization time (shorter than $5 \mathrm{~min}$ ), the use of low temperatures and the absence of contamination of sterilized material. To suppress growth and development of technophilic micromycetes, the photodynamic effect and vacuum are also used.

When using physical methods of struggle against biodamages, it should be considered that combined action of physical and chemical factors on microorganisms significantly increases the processing efficiency.

The use of special chemical reagents, toxic for microorganisms is one of the most widespread and effective protection methods for materials and products.

By type of action, toxicants are divided into biocides which kill biodamaging microbial agents; biostatics which decelerate microorganism propagation; and repellents which are deterrents for biodamage agents.

It is most desirable to apply biocides of the wide action range and mixture of various compounds given that microflora damaging materials and products are extremely variable and frequently include organisms from different groups. Of special interest are biocides with the limited life, because after a lapse of time the issue of material toxicity is withdrawn. From a practical standpoint, it is of interest to use polymeric biocides (organotin, etc.), more environmentally friendly than low-molecular compounds. "Chemical grafts" of preservative agents with active groups reacting with the polymer functional group to polymers are also of prospect $[25,26]$.

The application of biocides can be intended for two purposes: firstly, protection of materials against microorganism action; secondly, creation of materials protecting people against pathogenic microorganism action.

\subsection{Classification of Biocides}

Chemical protection means against biodamages are classified by the biological action, purpose and objects of application, and chemical composition. By biological (biocide) action, chemical protection means are:

- Fungicides - protecting materials and products against damages by fungi (mostly mold fungi);

- Bactericides - protecting against putrefactive, mucigenous, acid-forming and other bacteria;

- Algicides and molluscicides - protecting marine vessels, waterworks, industrial water supply and melioration systems against overgrowth by algae and mollusks;

- Insecticides - protecting wood, polymers, textile and other materials against damaging by termites, pests, moth, leather beetles and other insects;

- Herbicides - protecting buildings, structures, especially monuments of architecture, urban territories and construction sites, road sideways and railway embankments, and take-off runways against higher plants; 
- Zoocides - protecting against vertebrate animals - depredators: rodenticides - protecting against rats, mice and other rodents; avicides - protecting against birds incurring damage in cities and especially in airports.

By technical purpose and application, biocides are classified for the following groups of materials:

- Wood, paper, cardboard and other cellulosecontaining materials;

- Synthetic materials (plastics, rubbers, films, compounds, artificial leathers, etc.);

- Textile materials;

- Real leather and articles from it;

- Petroleum products (fuels, oils, lubricants);

- Lubricating fluids;

- Paints and coatings (including nonfouling ones), etc.

This classification is conditional to a definite extent, because due to a complex of biocidal and physicochemical properties many biocides can be used to protect several groups of materials.

By chemical composition, biocides are classified as follows: 1) inorganic compounds; 2) hydrocarbons, halohydrocarbons and nitro compounds; 3) alcohols, phenols and their derivatives; 4) aldehydes, ketones, organic acids and their derivatives; 5) amines, amine salts and quaternary ammonium compounds; 6 ) organoelement compounds; 7) heterocyclic compounds.

By the chemical composition, biocides having several functional groups or reaction sites in the molecule are usually classified to the group, considered to be responsible for the biocidal action.

In a number of cases, biocides used in practice represent mixtures of several substances rather than individual compounds. Such preparations are referred to one group or another by the main component, which generally determines its biocidal action.

The action mechanism of fungicides and bacteriocides is based on:

- the interaction with biologically important substances of the microorganism cell (cellular metabolites);

- suppression of enzyme activity;

- disturbance of the structure and functioning of biomembranes and cell walls.

The toxic action of biocides used for protection against biodamages of various materials and products is based on their ability to inhibit various reactions of microorganism metabolism and to degrade their cell structures. Primarily, biocide contacts with the cell cover and membrane, penetrate through them and just then interact with the intracellular content.

The toxic action of many fungicides on fungi begins manifesting already at their contact with the cell wall and the membrane. In contrast with the cover, cellular membranes are more multicomponent by the composition and more metabolically active. This determines their ability to interact with numerous chemical compounds. Changes in the membrane structure induced by antiseptics affect the activity of enzymes associated with the membrane.

The metabolic response of micromycetes to toxins penetration into their cells is manifested by disturbance of many biochemical reactions. Fungicides interact with a short number of functional groups of microbial cell substances; however, these are particularly groups playing the important role in metabolism and formation of cellular structures. Thiolic (sulfhydryl) group is the most frequently attacked one. The protein molecule structure, and consequently, their biological activity significantly depend on the presence and place of thiolic groups in the molecule.

Amino groups are other important acceptors of biocides in the cell. Along with thiolic groups, they determine the structure and biological activity of proteins. In the cell, fungicides also interact with the substances, which have carboxylic, aldehyde and alcohol groups in the molecule. Biocides may interact with the listed groups in different ways: by nucleophilic substitution, redox reactions, chelate formation, etc.

Toxicity of many biocides for microorganisms is stipulated by their inhibiting action on enzymes.

At present, several thousands of biocides from various classes of chemical compounds are descrided.

1. Inorganic compounds. A number of heavy metal cations are toxic for living organisms. By fungicide action intensity, basic metals are divided into three groups: the most toxic - silver, mercury, copper; medium toxicity cadmium, chromium, lead, cobalt, zinc; the lowest toxicity - iron, calcium.

Inorganic compounds were generally used as antiseptics for protection of wood, textile materials (copper and chromium salts), real leather (sodium fluoride and silicofluoride), paints (zinc and lead oxides, mercury bichloride); however, later they were substituted by more effective organic and organoelement compounds.

Curious facts. The history of the use of inorganic biocides reckons up several centuries. One of the earliest tests of these compounds was performed in the times of Peter the First. Having taken care of extending the lifetime of ships and having known the conservative action of Arcanum compound (copper sulfate) for the wood, he declared to test it for impregnating timber piles and to apply in places, where timber should be protected against putrefying.

2. Hydrocarbons, their halogen and nitro derivatives. Among hydrocarbons, diphenyl is generally used as biocide. It is low-toxic and, therefore, is used for impregnation of paper (along with paraffin) then used for wrapping citrus fruits during storage. 
The range of halogen and nitro derivatives of hydrocarbons used as biocides is wider and more diversified. Due to their high volatility, they can be used both as contact biocides for protection of real leather, paints, wood, polymer films and fumigating agents.

3. Alcohols, phenols and their derivatives. These compounds possess a wide spectrum of biocidal action. The biocide activity of phenols is much higher than that of alcohols. These are compounds, such as 2-oxy-diphenyl (injected at the stage of hide greasing, also used for conservation of fruits and vegetables), $n$-nitrophenol (protects real leather, is added to paints and varnishes), hexachlorophene (used in cosmetic creams, is added to plastics), pentachlorophenol (is widely used for cellulose material protection).

4. Aldehydes, ketones, organic acids and their derivatives. The most well-known biocide of this group is formaldehyde (40\% aqueous formaldehyde solution is called formalin). It is used for disinfection of warehouses, packaging materials, etc.

Cimide is added to PVC composition during manufacture of special purpose artificial leather.

Salicylanilide is used in production of biostable packing paper and cardboard and for textile materials protection.

Thiuram is added to the composition for rubber manufacture and is their best protection against overgrowth by mold fungi.

5. Amines, amine salts, quaternary ammonium compounds. This group includes metacide which has been recently, widely applied as a conserving agent for real leather, as well as an additive to paints and various polymeric coatings.

Catamine $A B$ is used for disinfection of fabrics, metal and wooden surfaces; it is injected to cement: for two or more years it will protect concrete against overgrowth.

6. Organoelement compounds. In these compounds, a metal or another element is bonded with one or more carbon atoms in the organic radical composition.

They are organmercury, organotin, organoarsenic and other compounds.

Among organomercury biocides, the most popular compounds are merthiolate (used as a volatile fungicide for protection of optical, radioelectronic and other devices), ethyl mercuric phosphate (used as antiseptic for wood, protein adhesives and for the control of mucus formation in the paper making industry).

The importance of organotin compounds for industry is so high that, despite high cost and deficiency of tin, the scope of their production reaches tens of thousands of tons. These compounds are able to protect various materials from biodamages.

Organoarsenic compounds are the following biocides: oxofin (is effective in the emulsion and oil paints), chlofin (incorporated in chlorine-containing polymers as a fungicide, light and thermal stabilizer).

7. Heterocyclic compounds. The most renowned biocides of this group are:

- Furacilin (used for lubricating fluids);

- Nitrofuryl acrolein (polyvinyl alcohol fiber "letilan" possessing a wide spectrum of antimicrobial action was synthesized);

- For many years (already since 1947), 8-oxyquinolate of copper (Cuprocin) is the leader among biocides protecting fabrics and paints, wood, paper and plastics. It is used for treatment of packing materials, compartments and equipment.

\subsection{Application of Antimicrobial M aterials}

Injection of antimicrobial additives into various materials preserves them from the impact of microorganisms under critical operation conditions and provides an opportunity to impart antimicrobial properties, e.g. stability under the impact of pathogens, to the goods. At the present time, antimicrobial nanomaterials, especially with silver nanoparticles, are widely applied.

These goods are famous antimicrobial socks and soap, detergents, etc. At present, more and more new products possessing these processes are manufactured. However, really necessary goods with antimicrobial properties should be distinguished from those, in which antimicrobial properties are used as a marketing technique to attract customers.

Due to the fact that antimicrobial textile materials can prevent spreading of bad smell occurring at a longterm contact of underwear and other things with the human body, appropriate articles from them are made specifically suitable for operation under conditions, when for some reason or another, personal hygiene measures cannot be applied.

Suppressing development of microorganisms on the human skin, antimicrobial clothes may hinder degradation of organics in the sweat composition, which products are direct source of odor. This allows recommendation of articles from antimicrobial materials to be used by persons, e.g. sailing in a long-term submerged run or being in the field. Hygienic properties of antimicrobial materials predetermine expedience of the use of articles from them as everyday things. For example, prophylaxis of fungus diseases is performed by applying hygienic finishing to needle-punched fabrics used as backings and inner soles, socks for soldiers, and shoe materials for sportsmen.

The use of towels and napkins with antimicrobial treatment in everyday life, in trains and aircrafts, and in offices is prospective, because they remain clean for a long 
time. Materials with antimicrobial activity for underlays on shelves and in boxes for storage and transportation of goods in the regions with increased humidity and temperature, as well as underlays at the bottom of waste bins in refuse collectors to eliminated bad smell and prevent mold formation are also widely used [25-30].

Antimicrobial materials are also important for manufacture of articles for the use in hospitals, such as whites, towels, handkerchiefs, swaddling-clothes, bedlinens, underwear, mattress-cases, blankets, especially in infectious medical institutions and maternity hospitals. Decorative articles from antimicrobial fabrics, such as curtains, hangings, drapery, etc., can also be used.

There are data in the literature on the application of needle-punched fabrics with antimicrobial activity, as floorings in hospitals, schools, sanatoriums, kindergartens, hotels and other public institutions, as well as in the everyday life. At present, there is an idea still that, comparing with smooth synthetic materials, nonwoven floorings represent an amassment of microbes. However, the application of biocides and wet cleaning may form a permanent disinfecting medium on nonwoven flooring. Floors can also be disinfected using antimicrobial materials for swabbing covers.

Wrapping and packaging materials with antimicrobial properties are of high practical importance. They provide long-term safety of packaged goods.

Antimicrobial clothes are also useful for technical purposes, as filtering materials, in particular. Filters with antimicrobial properties may be used for fresh water purifying and fruit juice conservation. Bacterial air filters are required for air conditioning and ventilation in hospitals and various microbiological laboratories. The requirement to technological air sterility is of importance for manufacture of various pharmaceutical and cosmetic preparations, vitamins and nutrimental citric acid; in this area, materials with predesigned antimicrobial properties may become of high practical importance.

\subsection{Requirements to Biocides}

The general requirement to any modern biocide is high activity in relation to harmful biofactors in combination with handling safety and the absence of adverse impact on the man and the environment.

Biocides should be accessible and relatively inexpensive.

Applied biocides must not affect physicochemical, physicomechanical and other properties of materials, and accelerate their aging and induce corrosion.

The basic requirements to biocides are hygienic ones - preparations should be low-toxic for animals and the man, not be accumulated in the environment, be allergens, etc.
Special requirements are also imposed on biocides and they are associated with particular features of protected material. For instance, biocides intended to protect against biodamages of polymeric and paint materials and applied as components of these materials must: be easily dissolved in organic solvents, be combined with other components of the material or be uniformly distributed in them, forming stable emulsion or suspension; be nonpolar compounds, if special requirements to electrophysical properties of the materials are imposed; not interact with protected material or its components.

Specific requirements are imposed on biocides for wood, which are also called wood antiseptics. They should easily penetrate and be stably fixed in the wood, partly, on the account of chemical interaction with it. Meanwhile, if the wood is desired to be a finishing material or intended for furniture manufacture, they must not affect the wood ability to be glued and dyed.

\subsection{Evaluation Methods for Antimicrobial Properties of Biocides}

The study of biocidal properties of the compounds and checking their efficiency in the material composition are mandatory for designing of chemical protectors of materials and products against biodamages.

At present, multiple biocide test methods are applied. Some of them are used only for determining separate biocidal properties. Other methods are used for determination of the protective ability and include both laboratory tests and tests under natural conditions (the field tests).

One of the most severe problems is development of effective protection means against damages induced by mold fungi and, therefore, the majority of new compounds are tested for fungicidal properties.

A number of laboratory methods are known, which assess fungicidal properties of various substances. The most applicable among them are reduced to fungi seeding on the surface of solid culture medium, into which by some means an antiseptic is injected. Then it is determined, if the substance under study hinders fungi propagation.

The standard test method of fungicide efficiency is based on assessment of kinetic parameters of fungi development on the culture medium containing fungicides.

The simplest laboratory method for assessment of antimicrobial properties of biocides on solid media is measurement of sizes of test-culture growth inhibition zones around the specimens (10 mm in diameter) of biocidal material or filtering paper discs impregnated by a biocide solution.

Antiseptic properties of everyday fabrics were tested as follows: fabric samples $2 \times 2 \mathrm{~cm}$ were placed in a Petri dish and grafted culture medium was added (Bacillus 
subtilis and Escherihia coli bacteria and Aspergillus niger fungus were used as test cultures). The evaluation criterion is culture growth expressed in points: 1 point the growth intensity above the specimen and around it is the same; 2 points - separate sprouted colonies above the specimen; 3 points - culture growth above the specimen is completely suppressed; 4 points - a zone of microorganism growth suppression $2 \mathrm{~mm}$ or less wide around the specimen is observed; 5 points - a zone of microorganism growth suppression over $2 \mathrm{~mm}$ wide around the specimen is observed.

\section{References}

[1] Ilichev V., Bocharov B. and Anisimov A.: Biopovregdeniya: [in:] Ilichev V. (Ed.) Biodamages: Uchebnoe Posobie dlya Specialistov-Biologov. Izd-vo Vyshei Shkoly, Moskwa 1987.

[2] Ilichev V., Bocharov B. and Gorlenko M.: Ekologicheskie Osnovy Zashity ot Biopovregdeniy. Nauka, Moskwa 1985.

[3] Ilichev V. (Ed.): Microorganizmy i Nizshye Rasteniya Razrushiteli Materialov i Izdelij. Nauka, Moskwa 1979.

[4] Bobkov T., Zlochevskaya V., Rudakov A. and Chekunova L.: Povregdeniya Promyshlennyh Materialov i Izdelij pod Deistviem Microorganizmov. Izd-vo MGU, Moskwa 1978.

[5] Lugauskas A., Mikulskeke A. and Shlyauzhene D.: Catalog Micromycetov -Biodestructorov Materialov. Nauka, Moskwa 1987.

[6] Pehtasheva E., Neverov A. and Sinizin N.: Die Rolle und Nutzung Mikrobiologischer Prozesse im Lebenszyklus von Materialien unter Besonderer Berücksichtigund von Textilien // Forum of ware, 2002, 30, 73.

[7] Eggins H. and Exley T.: Intern. Biodeterior. Bull, 1980, 16, 53.

[8] Salerno-Kochan R.: Proceed. Int. Conf. "Commodity research, science, practice and perspectives in the market conditions", Ukraine, Kiev 1999, 40.

[9] Danny A., Luanne R. and Warren P.: Text. Res. J., 1999, 69, 747.

[10] Raschle R.: Mikrobiologie in der textion Materialprüfund, Textilveredlung, 1987, 22, 381.

[11] Pekhtasheva E.: [in:] Neverov A. (Ed.): Biopovregdeniya i Zashchita Neprodovolstvennyh Tovarov, Masterstvo, Moskwa 2002.

[12] Neverov A. (Ed.): Proceeding of First All-Union Conference on the Biodamage, Nauka, Moskwa 1978.

[13] Plate N. (Ed.): Problemy Biologicheskogo Povregdeniya Materialov. Ecologicheskie Aspekty. Nauka, Moskwa 1988.

[14] Plate N. (Ed.): Ekologicheskie Problemy Biodegradacii Promyshlennyh, Stroitelnyh Materialov i Othodov Proizvodstv. Sbornik Materialov. Nauchn. Sovet po Biopovregdeniyam, Penza 2000 .
[15] Plate N. (Ed.): Zashchita Materialov i Tekhniki ot Povregdenij, Prichinyaemych Nasekomymi i Gryzunami, Nauchn. Sovet po Biopovregdeniyam. Sbornik Tezisov. Moskwa 1984.

[16] Ilichev V. (Ed.): Actualnye Voprosy Biopovregdeniy. Nauka, Moskwa 1983.

[17] Ilichev V. (Ed.): Actualnye Problemy Biologicheskikh Povregdeniy i Zashchity Materialov, Izdeliy i Soorugeniy. Nauka, Moskwa 1989.

[18] Smirnov V.: Ecologicheskie i Biologicheskie Aspekty Destrukcii Promyshlennykh Materialov Microorganismami. Nizhnii Novgorod State University, Nizhniy Novgorod 2002.

[19] Andreyuk E., Bilay V., Koval E. and Kozlov I.: Microbnaya Koroziya i eye Vozbuditeli. Naukova Dumka, Kiev 1980.

[20] Ilichev V. (Ed.): Biopovregdeniya i Metody Ocenko Biostoikosti Materialov. Nauka, Moskwa 1988.

[21] Cheshkova A., Lebedeva V. et al.: Pat. Russia 2070243, Publ. Dec. 10, 1996.

[22] Gumargalieva K. and Zaikov G.: Biodegradation and Biodeterioration of Polymers. Kinetical Aspects. Nova Science Publishers, New York 1998.

[23] Semenov S., Gumargalieva K. and Zaikov G.: About Biodegradation and Durability of Materials under the Effect of Microorganisms. VSP Int. Sci. Publ., Utrecht 2003.

[24] Ermilova I.: Teoreticheskie i Prakticheskie Osnovy Microbiologicheskoi Destrikcii Khimicheskikh Volokon. Nauka, Moskwa 1991.

[25] Sapozhnikova A.: Doctoral thesis, G.V. Plekhanov Institute, Moskwa, Russia, 1999.

[26] Wolf L. and Meos A.: Volokna Specialnogo Naznacheniya. Khimiya, Moskwa 1971. [27] Pekhtasheva E.: Doctoral thesis. Ros. Econom. Acad. im. G.V.Plekhanova, Moskwa, Russia, 2004.

[28] Moiseev Yu. and Zaikov G.:Chemical Resistance of Polymers in Reactive Media. Plenum Press, New York 1987.

[29] Emanuel N., Zaikov G. and Maizus Z.: Oxidation of Organic Compounds. Medium Effects in Radical Reactions. Pergamon Press, Oxford 1984.

[30] Jimenez A. and Zaikov G.: Polymer Analysis and Degradation. Nova Science Publ., New York 2000.

\section{КЛАСИФІКАЦІЯ БІОПОШКОДЖЕНЬ, МЕТОДИ ОЦІНЮВАННЯ І СПОСОБИ ЗАХИСТУ}

Анотація. Приведені класифікачія і діагностика біопошкоджень сировини, матеріалів і виробів, методи оиінювання біостійкості матеріалів $і$ методи захисту матеріалів від біопошкоджень. Розглянуто проблеми класифікаиії біоцидів, застосування антимікробних препаратів, вимоги до біочидів $i$ методи оцінювання антимікробних властивостей біоцидів.

Ключові слова: класифікачія, захист, методи оцінювання, діагностика, матеріали, сировина, біоциди, пестициди. 